Article

\title{
Why U.S. Consumers Buy Sustainable Cotton Made Collegiate Apparel? A Study of the Key Determinants
}

\author{
Ting Chi * Jenisha Gerard, Alison Dephillips, Hang Liu and Jing Sun
}

Department of Apparel, Merchandising, Design and Textiles, Washington State University, Pullman, WA 99164, USA; jenisha.gerard@wsu.edu (J.G.); alison.dephillips@wsu.edu (A.D.); hangliu@wsu.edu (H.L.); jing.sun@wsu.edu (J.S.)

* Correspondence: tchi@wsu.edu; Tel.: +1-509-335-8536

Received: 7 May 2019; Accepted: 30 May 2019; Published: 3 June 2019

\begin{abstract}
U.S. collegiate apparel is a $\$ 4$ billion market in which cotton and polyester made by conventional production methods account for $85 \%$ of materials used. Sustainable cotton made collegiate apparel offers a new opportunity for cotton made by novel and sustainable production methods to enter and replace conventional cotton and polyester for environmental protection and sustainable business development. This study aimed to provide insights on why U.S. consumers buy sustainable cotton made collegiate apparel and help understand the emerging trend of sustainable cotton apparel. Building on the Theory of Planned Behavior, an enhanced research model of consumer intent to purchase sustainable cotton made collegiate apparel (SCCA) is proposed. 225 eligible survey responses were gathered for data analysis and hypothesis testing. Attitude, subjective norms, perceived consumer effectiveness, and environmental knowledge positively influences U.S. consumers' purchase intentions toward SCCA while the effect of perceived behavioral control is insignificant. Furthermore, consumer environmental knowledge positively moderates the relationship between U.S. consumers' attitude and their purchase intentions. There are no significant differences between age groups, genders, education levels, or income levels among U.S. consumers in regards to their purchase intentions. The proposed research model exhibits a good explanatory power, accounting for $47.3 \%$ of the variance in U.S. consumers' purchase intentions toward SCCA.
\end{abstract}

Keywords: sustainable cotton; collegiate apparel; U.S. consumers; purchase intention

\section{Introduction}

In recent years, consumers are becoming increasingly concerned with the environmental consequences that their consumption behaviors can impose [1]. As defined by Chi [2], environmentally conscious consumers are consumers who buy goods and services that they believe to have a positive or less negative impact on the environment. A growing number of environmentally conscious consumers have shown to be willing to pay price premium for environmentally friendly products that lead to a new source of competitive advantage in business and are shifting firm focus to provide environmentally conscious consumers with more product options to meet their preferences, reflect their values, and represent their lifestyle [3-5]. This is particularly apparent in the U.S. textile and apparel industry that has long been considered one of the most environmentally unfriendly businesses [6-8]. Approximately 10 million tons of used textile and apparel end up in landfill or incineration in the U.S. every year [9]. The manufacturing processes of fiber, yarn, fabrics and apparel, and care of products consume a substantial amount of nonrenewable resources (e.g., water, energy) and discharge millions of gallons of effluent every year [10]. Furthermore, the chemicals used in pre-treatment, dyeing and finishing processes pose great environmental hazards and may cause severe health problems to people involved [6,11]. 
Given the considerable adverse impacts of the textile and apparel industry on the environment and the ever-increasing public concern about sustainability issues, a growing number of brands and firms have started looking into adoption of more sustainable practices [2,4,5]. Sustainable practice is considered a practice that supports economic and profitable growth, while helping to minimize environmental impact $[12,13]$. Cotton, marketed as "The Fabric of Our Lives", is a prominent material used for home textiles and apparel, and has been commonly mentioned in debates on sustainability [14]. Compared to the conventional production processes of cotton fibers, Cotton Incorporated [15] indicated that by implementing innovative technologies and tracking system the cotton could be grown and produced in more sustainable ways that could reduce the water, energy and chemical footprint by at least $50 \%$. The main areas of improvement for producing sustainable cotton fall into five categories: Process, chemicals and dyes, equipment, systems control and management, and wastewater treatment [15]. Through the Cotton LEADS ${ }^{\mathrm{TM}}$ program that is committed to sustainable cotton production and traceability throughout the entire cotton supply chain and is a global leader in promoting adoption of sustainable practices in cotton production, brands and retailers may source their textile and apparel products from the certified sustainable cotton manufacturers globally [16]. Many leading firms have partnered with the Cotton LEADS ${ }^{\mathrm{TM}}$ program, including Walmart, Target, Macy's, JC Penny, Kohl's, GAP, Brooks Brothers, etc. As more firms adopt sustainable cotton it will help continue to reduce land use, soil erosion, irrigation water used, nonrenewable energy used, and greenhouse gas emissions [13].

Among the growing interest in the use of cotton made by the sustainable production methods, research on the U.S. consumer willingness to buy sustainable cotton made collegiate apparel (SCCA) has not yet been done. Collegiate apparel that is apparel made for college sports teams for fans, alumni, and students/faculty to purchase to show their support to the team, has been one of the fastest growing segments in the U.S. apparel market. Compared to professional team-licensed apparel, such as NBA, NFL team-licensed apparel, collegiate apparel target consumers who are usually associated with specific universities. Different from function-based activewear, collegiate apparel is more versatile and can be worn on a daily basis although collegiate apparel has a 'sports element' in its design. Today, U.S. collegiate apparel is a $\$ 4$ billion industry in which conventionally made cotton and polyester account for over $85 \%$ of materials used [17]. Prior studies showed that U.S. consumers are relatively less price sensitive toward collegiate apparel [18]. Entering the collegiate apparel markets provides an opportunity for sustainable cotton to replace conventionally made cotton and polyester for environmental protection and grow long-lasting businesses. Furthermore, consumers want apparel to be able to transition from activity to activity, without the need to go home and change. The athleisure trend is a socially acceptable way to accomplish the consumers' desire for both apparel functionality and versatility [19]. This movement offers more potential for collegiate apparel growth and possible adoption of sustainable cotton.

In order to address the gap in the literature, this study aimed to provide insights on why U.S. consumers buy sustainable cotton made collegiate apparel (SCCA). Specifically, the objectives of this research are fourfold. First, building on the Theory of Planned Behavior (TPB), an enhanced consumer purchase intention towards SCCA is proposed. Second, the psychometric properties of the proposed model are tested using the gathered survey data. The validated model adds the theoretical contribution to the literature and may be applied in the future relevant studies. Third, the effects of significant factors on U.S. consumer purchase intention towards SCCA are determined. Finally, some marketing strategies are proposed for industrial practitioners. Understanding the determinants of US consumer willingness to purchase SCCA is critical in helping firms and brands to develop and implement effective marketing strategies to promote the consumption of sustainable cotton.

\section{Literature Review}

The review of the literature includes the Theory of Planned Behavior (TPB) that provide the theoretical framework for the study and basic constructs (i.e., attitude, subjective norms, and perceived behavioral control (PBC)) for the analysis, and additional constructs (i.e., perceived consumer 
effectiveness (PCE), and consumer environmental knowledge) that add theoretical reasoning and help to enhance the explanatory power of the original TPB. The research hypotheses are proposed based on the review of the literature.

\subsection{Theory of Planned Behavior (TPB)}

Ajzen and Fishbein [20] initially proposed the theory of reasoned action (TRA) that consists of three constructs-behavioral intention, attitude, and subjective norm. TRA argues that a person's behavioral intention depends on his/her attitude about the behavior and subjective norms. Behavioral intention measures a person's relative strength of intention to perform a behavior. In general, the stronger the intention to engage in a behavior, the more likely it will actually be performed [21]. Attitude consists of beliefs about the consequences of performing a behavior [20]. If a person has a positive attitude towards a particular behavior, he/she is more likely to form positive intentions towards it [22]. Subjective norm is viewed as a combination of perceived expectations from relevant individuals or groups along with intentions to comply with these expectations [20]. Thus, if a person believes significant others want him/her to perform a behavior and he/she is motivated to comply with, it is expected the person is more likely to perform the behavior [22,23].

To improve the predictive power of TRA, Ajzen [24] further introduced TPB by adding another construct named perceived behavioral control (PBC) to TRA. Ajzen [24] indicated that a person's intention to perform a specific behavior is expected to control the volitional factors that affect the behavior. These factors reveal the extent of efforts to make and the degree of willingness to try, of individuals, in order to produce the behavior [25]. Therefore, $\mathrm{PBC}$ is defined as a person's perception of the ease or difficulty of engaging in the behavior of interest [24].

\subsection{Attitude}

Attitude is recognized in cognitive psychology as one of the major factors guiding human behavior [26]. Attitude plays a crucial role between consumer purchase intention and other factors [27]. Positive relationships have been linked to consumer attitude and their willingness to buy environmentally friendly products $[5,28,29]$. Using a U.S. college student sample, Zheng and Chi [5] found that consumer positive attitudes toward environmentally friendly apparel (EFA) significantly affect their willingness to buy EFA. Chen and Deng [28] echoed that green purchase attitudes shown by consumers affect their intent to purchase green products. Another study reported that consumers who have enough information and shopping experience with sustainable textiles and apparel tend to develop positive attitudes toward the products, which in turn lead to stronger intention to purchase the products [29]. Based on these previous findings that support attitude as a consistently significant determinant for many sustainable product purchases, we propose the following hypothesis.

Hypothesis 1 (H1). Attitude towards sustainable cotton made collegiate apparel (SCCA) positively affects U.S. consumers' purchase intention towards SCCA.

\subsection{Subjective Norms}

Subjective norm is the perceived social force for carrying out a certain behavior. Subjective norm is considered a function of referent's beliefs, constituting social pressure placed upon consumers by their friends and families, and is considered before the individual performs a behavior [24]. Subjective norm helps understand how much a consumer feels morally responsible for others while purchasing sustainable products, and how important a positive social image is to the consumers [29]. Subjective norm is also crucial when predicting environmental-related behaviors [5,30], and green product consumption $[27,29]$. Prior studies have shown that consumers' subjective norms positively affect their intention to purchase environmentally friendly apparel $[5,22,29]$. When purchasing sustainable cotton made collegiate apparel, consumers might be influenced by environmentally active groups, media, 
and other activities that highlight the positive effects of purchasing sustainable apparel. Thus, the following hypothesis is proposed.

Hypothesis 2 (H2). Subjective norms positively affect U.S. consumers' purchase intention towards SCCA.

\subsection{Perceived Behavioral Control (PBC)}

PBC measures consumer perception of how simple or challenging it is to perform a behavior [31]. When consumers possess adequate opportunities and resources, fewer impediments or obstacles arise [21]. Consequently, their perceived control over a behavior becomes greater, which increases the likelihood of performing that behavior. Prior studies have shown a positive relationship between PBC and consumers' purchase intention toward environmentally friendly products $[5,29,32,33]$. Joergens [34] indicated that when consumers consider the price of a sustainable product is too high, they will exhibit lower PBC and tend to settle for less expensive traditional products instead. In that case, the premium price of the sustainable product has been seen as a challenge in the way of performing the intended behavior to purchase the product. Zheng and Chi [5] argued that, due to global sourcing and mass production, the price of environmentally friendly apparel is becoming less concerned to consumers while other factors, such as product availability and authenticity have emerged as critical factors for PBC. Similarly, Nam et al. [29] stressed that PBC towards purchasing environmentally friendly products may be affected by many factors, such as time, money, and capabilities. When the combined effects of these factors diminish PBC, the consumer will be less likely to purchase environmentally friendly products. Therefore, we propose the following hypothesis.

Hypothesis 3 (H3). PBC positively affects U.S. consumers' purchase intention towards SCCA.

\subsection{Advancement of TPB}

Building on the TPB, there have been some further developments aiming to help better understand the determinants of consumers' purchase intention towards environmentally friendly products. Additional antecedents and moderators, including consumer environmental knowledge and perceived consumer effectiveness (PCE) have been proposed and investigated by respective empirical studies [5, 22,35-37]. Inclusion of these constructs to the original TPB has helped to enhance the explanatory power of the TPB at different degrees for consumers' purchase intention towards environmentally friendly products. Therefore, this study integrated them into the TPB to develop an enhanced research model for understanding consumers' purchase intention towards sustainable cotton made collegiate apparel.

\subsubsection{Perceived Consumer Effectiveness (PCE)}

PCE was first proposed by Kinnear et al. [35] to study emerging environmentally conscious consumers. They found that consumers who perceived individuals could contribute to pollution reduction showed more environmental concerns and were more willing to change to environmentally friendly behaviors. In this view, PCE and attitude should be investigated as two distinct constructs [38]. The behaviors of individuals who perceive high consumer effectiveness are much more responsive to changes in environmental attitude than the behaviors of those who perceive less personal efficacy [5]. Purchase intention and behavior toward green products are affected by whether individuals believe or not their behaviors can lead to the desired outcome [37,39]. Roberts' [40] study showed that PCE is one of the best predictors of environmentally conscious consumer behavior, accounting for $33 \%$ of the variance in behavior. Zheng and Chi [5] demonstrated that PCE significantly affects consumers' purchase intention towards environmentally friendly apparel. They explained the reason that consumers are willing to buy environmentally friendly apparel is that they believe their actions or 
efforts of purchasing such products benefit environmental protection and human wellbeing. Thus, the following hypothesis is proposed.

Hypothesis 4 (H4). PCE positively affects U.S. consumers' purchase intention towards SCCA.

\subsubsection{Consumer Environmental Knowledge}

Environmental knowledge has been defined as the ability to recognize environmental problems, as well as the causes and consequences of problems [41,42]. A study examining the factors that influence sustainable consumption behaviors found a positive relationship between consumer environmental knowledge and their intent to purchase green products [43]. Researchers suggested that there are two forms of environmental knowledge: One is that consumers need to be educated to understand the impact of purchasing and consuming environmentally friendly products, and the second is consumers have access to the information that a product is being produced in an environmentally friendly manner [44]. Consumers are constantly seeking product knowledge, which is why it's important for companies to label their products to bring awareness of the impact of a product. Consumers with environmental knowledge have shown a greater likelihood to purchase environmentally friendly products compared to those consumers who don't have the knowledge $[45,46]$. In a study that investigated the antecedents of environmentally friendly purchase behavior among young consumers, Lee [47] proved that consumers' environmental knowledge accounts for $12 \%$ of the total variance in explaining their purchase behavior. Yadav and Pathak [48] reported that the inclusion of environmental knowledge in the TPB proves itself to be a significant predictor of consumers' intention towards buying green products. In addition to the direct effect, some prior studies also found that consumers' environmental knowledge can moderate the relationship between attitude and purchase intention towards environmentally friendly products $[5,22,29,49]$. Zheng and Chi [5] proved that a higher level of knowledge on environmentally friendly apparel improves the strength between consumer attitude and purchase intention towards environmentally friendly apparel. Therefore, the following hypotheses are proposed.

Hypothesis 5 (H5). Environmental knowledge positively affects U.S. consumers' purchase intention towards SCCA.

Hypothesis 6 (H6). Environmental knowledge positively moderates the relationship between U.S. consumers' attitude towards SCCA and their intent to purchase SCCA.

\section{The Proposed Model and Developed Survey Instrument}

Based on the above extensive literature review, a research model with developed hypotheses is proposed to reveal the antecedents and moderator of U.S. consumer purchase intention towards sustainable cotton made collegiate apparel. The model is illustrated in Figure 1. The survey instrument consists of one section to collect demographic information, including gender, ethnicity, age, income and education and multiple sections to gather the responses to the measures of antecedents, moderator and purchase intention in the proposed model.

The scales for purchase intention (PI), attitude (AT), and subjective norm (SN) were adapted from Nam et al. [29]. The scales for perceived behavioral control (PBC) and perceived consumer effectiveness (PCE) were adapted from Zheng and Chi [5]. The scale for environmental knowledge (EK) was adapted from Barbarossa and Pelsmacker [46]. Table 1 lists all the constructs and their corresponding measurement scales. 


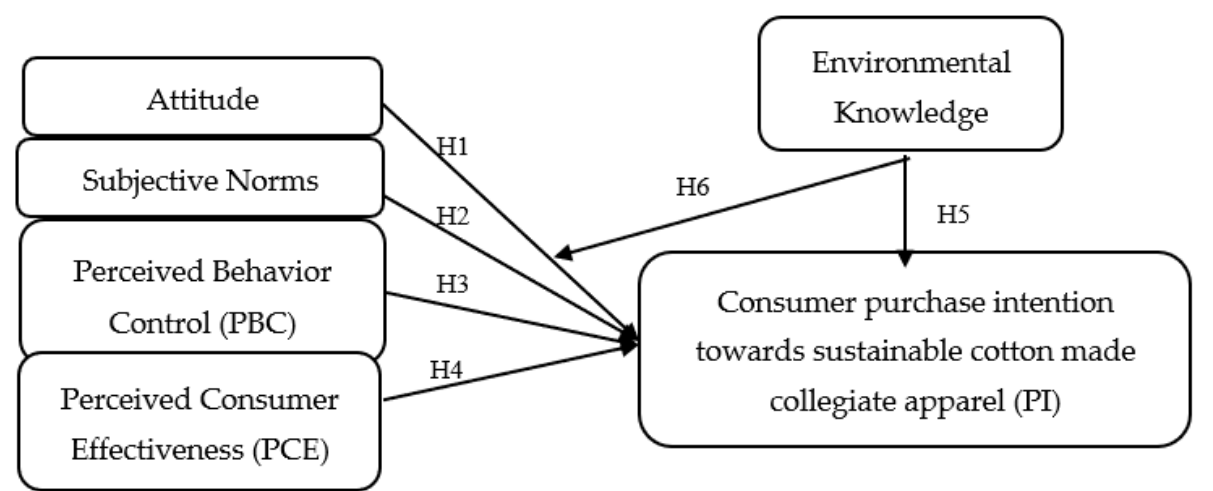

Figure 1. The proposed research model.

Table 1. Constructs and corresponding measurement scales.

\begin{tabular}{|c|c|c|}
\hline Construct & Measure and Scale [Factor Loading] & Source \\
\hline Purchase Intention (PI) & $\begin{array}{l}\text { PI1: I intend to buy sustainable cotton made collegiate } \\
\text { wear. [0.813] } \\
\text { PI2: I will try to buy sustainable cotton made } \\
\text { collegiate wear in the future. [0.902] } \\
\text { PI3: I will make an effort to buy sustainable cotton } \\
\text { made collegiate wear in the future. [0.907] }\end{array}$ & Nam et al. [29] \\
\hline Attitude (AT) & $\begin{array}{l}\text { AT1: I like the idea of purchasing sustainable cotton } \\
\text { made collegiate wear. [0.802] } \\
\text { AT2: Sustainable cotton made collegiate wear } \\
\text { purchase behaviors is a good idea. [0.805] } \\
\text { AT3: I have a favorable attitude towards sustainable } \\
\text { cotton made collegiate wear purchase behaviors. } \\
\text { [0.801] }\end{array}$ & Nam et al. [29] \\
\hline Subjective Norm (SN) & $\begin{array}{l}\text { SN1: Close friends and family think it is a good idea } \\
\text { for me to buy sustainable cotton made collegiate wear. } \\
\text { [0.853] } \\
\text { SN2: The people who I listen to could influence me to } \\
\text { buy sustainable cotton made collegiate wear. [0.760] } \\
\text { SN3: Important people in my life want me to buy } \\
\text { sustainable cotton made collegiate wear. [0.776] }\end{array}$ & Nam et al. [29] \\
\hline $\begin{array}{l}\text { Perceived Behavioral } \\
\text { Control (PBC) }\end{array}$ & $\begin{array}{l}\text { PBC1: Purchasing sustainable cotton made collegiate } \\
\text { wear was entirely within my control. [0.850] } \\
\text { PBC2: I had the resources and ability to acquire } \\
\text { sustainable cotton made collegiate wear. [0.792] } \\
\text { PBC3: I have complete control over the number of } \\
\text { sustainable cotton made collegiate wear that I will } \\
\text { buy for personal use. [0.830] }\end{array}$ & Zheng and Chi [5] \\
\hline $\begin{array}{l}\text { Perceived Consumer } \\
\text { Effectiveness (PCE) }\end{array}$ & $\begin{array}{l}\text { PCE1: By purchasing sustainable cotton made } \\
\text { collegiate wear, every consumer can have a positive } \\
\text { effect on the environment. [0.895] } \\
\text { PCE2: Every person has the power to influence } \\
\text { environmental problems by purchasing sustainable } \\
\text { cotton made collegiate wear. [0.852] } \\
\text { PCE3: It does not matter whether I purchase } \\
\text { sustainable cotton made collegiate wear or not since } \\
\text { one person acting alone cannot make a difference.* } \\
\text { [Dropped due to low factor loading] }\end{array}$ & Zheng and Chi [5] \\
\hline $\begin{array}{l}\text { Environmental Knowledge } \\
\text { (EK) }\end{array}$ & $\begin{array}{l}\text { EK1: I think of myself as someone who has } \\
\text { environmental knowledge. [0.850] } \\
\text { EK2: I know buying sustainable cotton made } \\
\text { collegiate wear is good for the environment. [0.868] } \\
\text { EK3: I have taken a class or have been informed on } \\
\text { sustainability issues concerning cotton. [Dropped due } \\
\text { to low factor loading] }\end{array}$ & $\begin{array}{l}\text { Barbarossa and } \\
\text { Pelsmacker [46] }\end{array}$ \\
\hline
\end{tabular}

Note-five-point Likert scale from "Strongly disagree $=1$ " to "Strongly agree $=5$ ". * Reversed measures. PCE3 and EK3 are dropped, due to low factor loading. 


\section{Methodology}

In this section, we firstly introduce survey instrument development and data collection procedure. Then data analysis methods are explained in detail.

\subsection{Survey Instrument Development and Data Collection Procedure}

The developed survey instrument was firstly reviewed by three experienced professors on the subject and then pre-tested with 10 U.S. consumers. The suggestions from the participants were used to refine the instrument with regard to arrangement, wording accuracy, and relevance [50]. This process helped to make the final survey instrument more valid and clearer [51].

The primary data was collected by an online survey of U.S. consumers who have shopped collegiate apparel previously. The professional survey platform used is Amazon Mechanical Turk (https://www.mturk.com), which can reach a wide range of consumers with high reliability and generate a random sample to avoid response bias [52]. Compared with conventional survey methods, an online survey has its advantages, including less time and money costs, convenience for respondents, and automation [53]. A total of 225 eligible responses were received. The profile of survey respondents is presented in Table 2.

Table 2. Profile the survey respondents.

\begin{tabular}{|c|c|c|c|}
\hline \multicolumn{3}{|c|}{ Percentage } & \multirow[t]{2}{*}{ Percentage } \\
\hline Gender & & Education level & \\
\hline Male & $52.2 \%$ & High school & $12 \%$ \\
\hline \multirow[t]{2}{*}{ Female } & $47.8 \%$ & Some college & $34.2 \%$ \\
\hline & & Bachelor's degree & $42.2 \%$ \\
\hline Age & & Master's degree & $9.8 \%$ \\
\hline $18-25$ & $14.7 \%$ & Doctorate & $1.8 \%$ \\
\hline $26-30$ & $25.3 \%$ & $\begin{array}{c}\text { Annual household } \\
\text { income (before taxation) }\end{array}$ & \\
\hline $31-35$ & $18.7 \%$ & Less than $\$ 5000$ & $2.7 \%$ \\
\hline $36-40$ & $12 \%$ & $\$ 5000$ to $\$ 9999$ & $2.7 \%$ \\
\hline $41-45$ & $9.8 \%$ & $\$ 10,000$ to $\$ 14,999$ & $4.4 \%$ \\
\hline $46-50$ & $6.2 \%$ & $\$ 15,000$ to $\$ 24,999$ & $12.4 \%$ \\
\hline 51 or older & $13.3 \%$ & $\$ 25,000$ to $\$ 34,999$ & $17.3 \%$ \\
\hline Ethnicity & & $\$ 35,000$ to $\$ 49,999$ & $12.4 \%$ \\
\hline White, Caucasian & $73.8 \%$ & $\$ 50,000$ to $\$ 74,999$ & $23.6 \%$ \\
\hline African American, Black & $9.3 \%$ & $\$ 75,000$ to $\$ 99,999$ & $11.6 \%$ \\
\hline Hispanic, Latino & $6.7 \%$ & $\$ 100,000$ and more & $12.9 \%$ \\
\hline Asian, Pacific islanders & $7.6 \%$ & $\begin{array}{c}\text { Annual expenditure on } \\
\text { apparel }\end{array}$ & \\
\hline \multirow[t]{5}{*}{ Others } & $2.7 \%$ & $\$ 0-299$ & $33.8 \%$ \\
\hline & & $\$ 300-499$ & $23.1 \%$ \\
\hline & & $\$ 500-899$ & $26.7 \%$ \\
\hline & & $\$ 900-1499$ & $9.8 \%$ \\
\hline & & $\$ 1500$ or more & $6.7 \%$ \\
\hline
\end{tabular}

Note-Two hundred and twenty-five eligible responses.

Of 225 respondents, $48.4 \%$ were female and $51.6 \%$ were male. The ages of the respondents varied from 18 years old to over 50 years old, mainly distributing $(70 \%)$ in the range of 18 to 40 years old. Most of the respondents had some college education or bachelor's degree $(76.4 \%)$, followed by high school $(12 \%)$, master's degree $(9.8 \%)$, and doctorate (1.8\%). In terms of ethnicity, a majority of the respondents were White, Caucasian at 73.8\%, followed by African American, Black at 9.3\%, Asian, Pacific islanders at $7.6 \%$, Hispanic, Latino at $6.7 \%$, and others at $2.7 \% .53 .3 \%$ of the respondents' personal pre-tax income ranged from $\$ 25,000$ to $\$ 74,999$, followed by $\$ 100,000$ and more at $12.9 \%$, $\$ 15,000$ to $\$ 24,999$ 
at $12.4 \%, \$ 75,000$ to $\$ 99,999$ at $11.6 \%, \$ 10,000$ to $\$ 14,999$ at $4.4 \%$, both less than $\$ 5000$ and $\$ 5000$ to $\$ 9999$ at $2.7 \%$. With regard to annual total expenditure on apparel, $33.8 \%$ of the respondents indicated they spent between $\$ 0-299$, followed by $26.7 \%$ at $\$ 500-\$ 899$, followed by, $23.1 \%$ at $\$ 300-499,9.8 \%$ at $\$ 900-1499$, and $6.7 \%$ with $\$ 1500$ or more.

\subsection{Data Analysis Methods}

The statistical assumptions, including multivariate normality, multicollinearity, and correlations, were first examined. Multivariate normality is met when each variable under consideration is normally distributed with respect to each other variable, which can be assessed through the inspection of univariate distribution index values (i.e., skewness and kurtosis for each variable). There is a violation of normality assumption, if skewness and kurtosis are greater than +1.0 or smaller than -1.0 [54].

Multicollinearity is a statistical phenomenon in which two or more predictor variables in a multiple regression model are highly correlated, meaning that one can be linearly predicted from the others with a non-trivial degree of accuracy. To test multicollinearity among the predictor variables, variance-inflation factor (VIF) were applied. The VIF values should be less than 5.0 to indicate that no multicollinearity problem occurs [55].

Since each construct was measured by multiple items, the average score of the multi-items for a construct was computed and used in further analysis, such as correlation analysis and multiple regression analysis [50,56-59]. Pearson correlation analysis was applied to examine the relationship between the constructs. The correlation coefficient value (r) range from 0.10 to 0.29 is considered weak, from 0.30 to 0.49 is considered medium and from 0.50 to 1.0 is considered strong [60,61]. A confirmatory factor analysis (CFA) was employed to test the constructs in the proposed model in terms of reliability, unidimensionality, and construct validity, including both convergent validity and discriminant validity. For factor analysis, the extraction criterion is set as eigenvalue above 1.0. Items with low factor loadings (less than 0.50) are dropped [62]. The deduction of certain measurement variables requires the re-examination of factor loadings, coefficient alpha, item-to-total correlations, and factor structure [50]. This iterative procedure is repeated until all requirements are met.

Unidimensionality, reliability, convergent validity, and discriminant validity were tested for proving model adequacy. Unidimensionality refers to the existence of one underlying measurement construct that accounts for variation in examinee responses [54]. Cronbach's alpha is a coefficient of internal consistency, which is commonly used to test the reliability of a construct. Convergent validity refers to the extent to which indicators of a specific construct 'converge' or share a high proportion of variance in common [63]. Convergent validity is valid when Average Variance Extracted (AVE) scores for all latent constructs are above the desired threshold of 0.50. AVE is a summary measure of convergence among a set of measurement items representing a construct. Discriminant validity refers to the extent to which a construct is truly distinct from other constructs. The AVEs should be greater than the squared correlation between the two constructs of interest to demonstrate satisfactory discriminant validity $[64,65]$.

Multiple regression analysis is applied to analyze the statistical relationships between the dependent variable and independent variables [66]. Therefore, multiple regression analysis was selected as an appropriate method for this study to test the hypotheses. Statistical Package for the Social Sciences (SPSS) software (IBM Corporation, Armonk, NY, USA, Version 24) was used for statistical assumption tests, model adequacy examinations and multiple regression analysis.

\section{Results and Discussions}

\subsection{Statistical Assumption Examination, Factor Analysis, and Construct Adequacy}

Table 3 presents the correlations and properties of all constructs. All skewness and kurtosis scores are between +1.0 and -1.0 , which suggest there are no violations of the normality assumption. All VIF values are below five, suggesting there are no multicollinearity issues among constructs and 
variables. After exploratory factor analysis, the measurement variables labelled as PEC3 and EK3 are dropped, due to low factor loading (see Table 1 ). All the factor loadings of the remaining measurement items to their respective constructs are high ( 0.6 and higher) and statistically significant, while their loadings to other constructs are very low ( 0.3 and lower). This also shows unidimensionality for the constructs. In addition, the Chi-square tests of all constructs were insignificant, which established evidence of unidimensionality. Cronbach's alphas of all constructs are greater than 0.70 , indicating reliability is rigorously met [64]. The AVE scores for all constructs are above the desired threshold of 0.50, suggesting convergent validity. All AVE scores are greater than the squared corresponding correlations, which demonstrate satisfactory discriminant validity.

Table 3. Correlations and properties of all constructs.

\begin{tabular}{ccccccc}
\hline & AT & SN & PBC & PCE & EK & PI \\
\hline AT & 1 & $0.157^{* *}$ & $0.384^{* *}$ & $0.512^{* *}$ & $0.355^{* *}$ & $0.498^{* *}$ \\
SN & 0.002 & 1 & $0.151^{* *}$ & $0.144^{* *}$ & $0.360^{* *}$ & $0.350^{* *}$ \\
PBC & 0.147 & 0.023 & 1 & $0.269^{* *}$ & $0.279^{* *}$ & $0.311^{* *}$ \\
PCE & 0.262 & 0.021 & 0.072 & 1 & $0.324^{* *}$ & $0.496^{* *}$ \\
EK & 0.126 & 0.130 & 0.078 & 0.105 & 1 & $0.410^{* *}$ \\
PI & 0.248 & 0.123 & 0.097 & 0.246 & 0.168 & 1 \\
\hline Mean & 3.17 & 3.03 & 2.87 & 3.03 & 3.32 & 3.12 \\
S.D. & 0.98 & 0.86 & 1.12 & 1.07 & 1.02 & 1.05 \\
Cronbach's alpha & 0.877 & 0.709 & 0.764 & 0.816 & 0.731 & 0.847 \\
AVE & 0.643 & 0.636 & 0.680 & 0.763 & 0.738 & 0.776 \\
$x^{2}$ test $p$ value & 0.087 & 0.115 & 0.079 & 0.068 & 0.073 & 0.062 \\
Skewness & -0.953 & 0.024 & -0.504 & -0.732 & -0.983 & -0.777 \\
Kurtosis & -0.212 & 0.314 & -0.988 & -0.541 & 0.271 & -0.425 \\
\hline
\end{tabular}

Note- the italic numbers are the squared corresponding correlations. ${ }^{* *}$ correlation is significant at the 0.01 level (2-tailed). AT = attitude, $\mathrm{SN}=$ subjective norms, $\mathrm{PBC}=$ perceived behavioral control, $\mathrm{PCE}=$ perceived consumer effectiveness, $\mathrm{EK}=$ environmental knowledge, $\mathrm{PI}=$ purchase intention, $\mathrm{GEN}=$ gender, ETHN = ethnicity, EDU = education, INC = income.

\subsection{Hypothesis Testing Results and Discussion}

Once the adequacies of all constructs were demonstrated, the proposed hypotheses were tested using multiple regression technique. A single score was obtained for each construct by averaging across the measurement items [50,56-59]. Table 4 presents the results of hypothesis testing. Among six proposed hypotheses, five of them (H1-6) were statically significant at a $p<0.05$ level and H3 was insignificant. The effects of demographic variables on U.S. consumer purchase intention towards sustainable cotton made collegiate apparel were all insignificant at a $p<0.05$ level.

Table 4. Results of hypothesis testing.

\begin{tabular}{|c|c|c|c|c|c|c|c|c|c|c|c|c|}
\hline \multicolumn{2}{|c|}{ Hyp. } & \multirow{2}{*}{$\begin{array}{c}\text { DV } \\
\text { PI }\end{array}$} & \multirow{2}{*}{$\begin{array}{c}\text { IDV } \\
\text { Constant }\end{array}$} & \multirow{2}{*}{$\begin{array}{c}\begin{array}{c}\text { Std. } \\
\text { Coef. }(\beta)\end{array} \\
-\end{array}$} & \multirow{2}{*}{$\begin{array}{c}t \text {-Value } \\
-2.132\end{array}$} & \multirow{2}{*}{$\begin{array}{c}\begin{array}{c}\text { Sig. at } \\
p<0.05\end{array} \\
0.034\end{array}$} & \multirow{2}{*}{$\begin{array}{c}\begin{array}{c}\text { Control } \\
\text { Variable }\end{array} \\
\text { Age }\end{array}$} & \multirow{2}{*}{$\begin{array}{c}\begin{array}{c}\text { Std. Coef. } \\
(\boldsymbol{\beta})\end{array} \\
0.025\end{array}$} & \multirow{2}{*}{$\frac{t \text {-Value }}{0.486}$} & \multirow{2}{*}{$\begin{array}{c}\text { Sig. at } \\
p<0.05\end{array}$} & \multirow{2}{*}{$\begin{array}{c}\text { Total } \\
\boldsymbol{R}^{2}\end{array}$} & \multirow{3}{*}{$\begin{array}{c}\text { Sig. at } \\
p<0.05 \\
<0.001 \\
F= \\
17.34 \\
(10 / 214)\end{array}$} \\
\hline & & & & & & & & & & & & \\
\hline H1 & Y & & AT & 0.588 & 6.045 & $<0.001$ & Gender & -0.007 & -0.145 & 0.885 & & \\
\hline $\mathrm{H} 2$ & $\mathrm{Y}$ & & $\mathrm{SN}$ & 0.175 & 3.219 & 0.001 & Education & 0.042 & 0.807 & 0.421 & & \\
\hline $\mathrm{H} 3$ & $\mathrm{~N}$ & & PBC & 0.101 & 1.810 & 0.072 & Income & 0.072 & 1.376 & 0.170 & & \\
\hline $\mathrm{H} 4$ & $\mathrm{Y}$ & & PCE & 0.237 & 3.975 & $<0.001$ & & & & & & \\
\hline H5 & $\mathrm{Y}$ & & EK & 0.451 & 5.005 & $<0.001$ & & & & & & \\
\hline H6 & $\mathrm{Y}$ & & $\mathrm{AT}^{*} \mathrm{EK}$ & 0.571 & 4.565 & $<0.001$ & & & & & & \\
\hline
\end{tabular}

Note-Y-Hypothesis supported; $\mathrm{N}-$ Hypothesis not supported; $\mathrm{PI}=$ purchase intention, $\mathrm{AT}=$ attitude, $\mathrm{SN}=$ subjective norms, $\mathrm{PBC}=$ perceived behavioral control, $\mathrm{PCE}=$ perceived consumer effectiveness, $\mathrm{EK}=$ environmental knowledge. $\mathrm{AT}^{*} \mathrm{EK}=$ moderator. Std. Coef. = standardized coefficients, $\mathrm{DV}=$ dependent variable. $\mathrm{IDV}=$ independent variable. 
Specifically, attitude positively affects U.S. consumer purchase intention towards sustainable cotton made collegiate apparel $(\beta=0.588, t=6.045)$, supporting H1. This indicates that U.S. consumers who show positive attitudes toward sustainable cotton made collegiate apparel are more likely to purchase the products. This finding is aligned with previous findings on the relationship between consumer attitude and purchase intention towards sustainable textile or apparel products from Lee [47], Nam et al. [29], and Zheng and Chi [5]. Similarly, subjective norms positively influence U.S. consumer purchase intention $(\beta=0.175, t=3.219)$, supporting $\mathrm{H} 2$. This shows that if a consumer believes significant others or socially active groups want or encourage him/her to purchase sustainable cotton made collegiate apparel and he/she is motivated to comply with, it is expected the person is more likely to perform the behavior. This result meshes with the previous finding from Lee [25], Nam et al. [29], and Zheng and Chi [5]. Perceived consumer effectiveness (PCE) significantly affects U.S. consumer purchase intention towards sustainable cotton made collegiate apparel $(\beta=0.237, t=3.975)$, supporting $\mathrm{H} 4$. This reveals that a higher level of confidence in individual contribution to environment protection through purchasing sustainable cotton made collegiate apparel leads to greater purchase intention. This finding corroborates the significant predictability of PCE for consumer environmentally friendly behavior $[5,22,29]$. Environmental knowledge significantly influences U.S. consumer purchase intention towards sustainable cotton made collegiate apparel $(\beta=0.451, t=5.005)$, supporting H5. Understanding the environmental benefits of producing and consuming sustainable products improves consumers' willingness to buy sustainable cotton made collegiate apparel $[5,22,29,47]$. Furthermore, the moderating effect of environmental knowledge on the relationship between attitude and purchase intention is positively significant $(\beta=0.571, t=4.565)$, supporting H6. This indicates that a higher level of environmental knowledge enhances the strength of the relationship between U.S. consumers' attitudes and their intent to purchase sustainable cotton made collegiate apparel, which is consistent with the previous finding on the moderating effect of environmental knowledge $[5,22,49,67]$. The only statistically insignificant relationship is the effect of $\mathrm{PBC}$ on U.S. consumer purchase intention towards sustainable cotton made collegiate apparel $(\beta=0.101, t=1.810)$. H3 was not supported. This finding adds new evidence supporting some recent argument that U.S. consumers are becoming less concerned about if they may control over their sustainable consumption behavior as the availability and affordability of sustainable products in the U.S. market are no longer major issues $[5,68,69]$.

Figure 2 illustrates the identified relationships in the proposed research model. Attitude, subjective norms, perceived consumer effectiveness, and environmental knowledge positively affects U.S. consumer purchase intention towards sustainable cotton made collegiate apparel while the effect of perceived behavior control is insignificant. Environmental knowledge positively moderates the relationship between attitude and U.S. consumer purchase intention. There are no significant differences between age groups, genders, ethnical groups, education levels, or income levels among U.S. consumers in regards to their intent to purchase sustainable cotton made collegiate apparel. The proposed research model exhibits a good explanatory power, accounting for $47.3 \%$ of the variance in U.S. consumers' purchase intention towards sustainable cotton made collegiate apparel. 


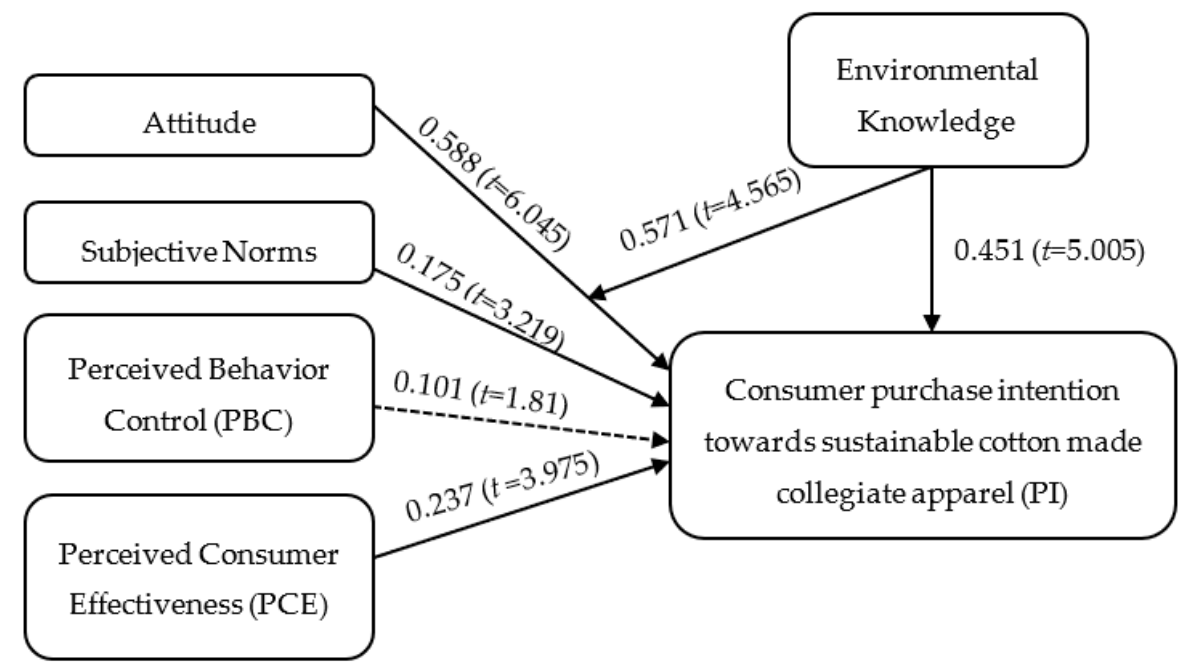

Figure 2. Identified relationships in the research model.

\section{Conclusion and Implications}

The textile and apparel industry had a tremendous effect on the natural environment and its resources. In recent years, an increasing number of firms and brands have begun to make more efforts to relieve the negative impacts this industry has on the environment and fulfill the growing demand on sustainable products by environmentally conscious consumers. In order to do so, businesses need to assess where and how their materials are grown, and make sure their products meet the quality and sustainability standards. Among many increasingly available sustainable materials, sustainable cotton as the viable replacement for conventionally made cotton and polyester has been gaining popularity in various apparel categories, including the lucrative collegiate apparel segment. However, our knowledge on the key factors driving the U.S. consumers' purchase intention towards sustainable cotton made collegiate apparel (SCCA) is scant. Furthermore, the empirical findings of consumer purchase intention towards other environmentally friendly products cannot be simply generalized to SCCA $[5,29]$. Re-examination of prior findings in the context of SCCA is needed. The great potential of U.S. collegiate apparel market for sustainable cotton adoption provides a solid rationale for this study.

Overall, the major contributions of this study to the current literature are fourfold. First, building on the TPB model, additional factors and moderator (i.e., PCE, environmental knowledge) were included to propose an enhanced consumer purchase intention model for SCCA. The proposed research model exhibits a good explanatory power, accounting for $47.3 \%$ of the variance in U.S. consumers' purchase intention towards SCCA. Second, since the model provides significant statistical findings, it offers a valid and reliable tool to investigate consumer purchase intention towards other sustainable products or in a different country context. Third, in addition to the strong accountability of the traditional TPB constructs, some new findings from the enhanced model add special insights to the understanding of U.S. consumers' purchase intention towards SCCA. Specifically, the extent to which an individual believes that his/her consumption behavior can effectively contribute to pollution abatement and environmental protection affects his/her purchase intention. Consumer environmental knowledge plays a vital role in both the direct effect on their purchase intention, and the indirect moderating effect on attitude and purchase intention nexus. Lastly, although there are no statistically significant differences detected among demographic variables in regards to U.S. consumer purchase intention towards SCCA, age, education level, and income level show positive correlations with U.S. consumer purchase intention while gender exhibits negative relationships with U.S. consumer purchase intention. These findings on demographics may provide valid references to segment U.S. consumers for SCCA.

This study also imparts some managerial implications. The empirical finding shows that U.S. consumer attitude influences their purchase intentions. Firms should develop marketing strategies and 
promotional campaigns to cultivate and promote favorable attitudes among target consumers toward SCCA. In advertisements, companies should emphasize on the importance of SCCA consumption in doing well for future generations and the preservation of the natural environment.

As the effect of attitude on purchase intention is enhanced by U.S. consumer environmental knowledge, and the increase in the environmental knowledge also directly leads to higher purchase intention, clear information regarding how SCCA may help conserve natural resources and about the exact benefits that consumption of SCCA to sustainability compared to conventionally made cotton or polyester apparel should be stated in the product labels and advertisements.

The U.S. consumers' purchase intention towards SCCA is influenced by the perceived social pressures and their willingness to comply with such pressures. If relevant groups (i.e., families, friends, and active social groups) purchased or encouraged to purchase SCCA, the higher social pressure could be exerted on these consumers to buy such products. The information through word-of-mouth or influential social media may play a critical role in attracting potential consumers for sustainable cotton made colligate apparel.

PCE has a significant influence on consumers' purchase intention. Firms and brands should make more efforts to convince consumers that their consumption of SCCA would contribute to the preservation of environmental and human wellbeing. Advertisements could emphasize the fact that it is possible to alleviate the environmental deteriorations through individual's consumption behavior. In an industrial level, PCE could be improved through creating an industry-wide standard to rate the products' greenness. At a firm level, PCE could be enhanced among consumers by offering transparent sustainable cotton apparel information, such as how the products were produced, what materials were used, how the new production process is less impactful to the environment. It is crucial to educate consumers about the difference between sustainable cotton made colligate apparel and traditional cotton or polyester made colligate apparel in terms of their attributes and environmental impacts.

\section{Limitations and Further Studies}

Although this study has contributed to the understanding of U.S. consumers purchase intention towards sustainable cotton made collegiate apparel, it still includes some limitations. First, it should be noted that the conclusions and implications in this study are limited to the enhanced TPB model. The generalization of the findings towards other environmentally friendly and sustainable cotton made products, or other groups of consumers, requires further validation. Second, because this study is focused on sustainable cotton made apparel, the survey instrument is product specific. There are also many other sustainable fibers that could potentially replace conventional polyester and provide good use properties. The application of the survey instrument to other sustainable material made products calls for appropriate revisions. Finally, the study took a quantitative approach. Although the quantitative method allows for the examination of the causal relationships between individual factors and U.S consumers purchase intention towards sustainable cotton made collegiate apparel, it is weak in uncovering the underlying themes and reasons to the phenomenon. Qualitative methods used in future studies may provide more detailed reasoning regarding the relationships identified in the quantitative analysis done in this study.

Author Contributions: Lead author-T.C. is also the principal investigator of the funded project. T.C., J.G., and A.D. designed the research, reviewed the literature, developed the survey questionnaire, analyzed the data and wrote the paper. H.L. and J.S. contributed to the literature review and paper preparation.

Acknowledgments: This project is using a grant from the Importer Support Program of the Cotton Board and with supervision from Cotton Incorporated.

Conflicts of Interest: The authors declare no conflict of interest. 


\section{References}

1. Bong Ko, S.; Jin, B. Predictors of purchase intention toward green apparel products: A cross-cultural investigation in the USA and China. J. Fash. Mark. Manag. Int. J. 2017, 21, 70-87. [CrossRef]

2. Chi, T. Consumer perceived value of environmentally friendly apparel: An empirical study of Chinese consumers. J. Text. Inst. 2015, 106, 1038-1050. [CrossRef]

3. Ellis, J.; Mccracken, V.; Skuza, N. Insights into willingness to pay for organic cotton apparel. J. Fash. Mark. Manag. Int. J. 2012, 16, 290-305. [CrossRef]

4. Nassivera, F.; Troiano, S.; Marangon, F.; Sillani, S.; Nencheva, I.M. Willingness to pay for organic cotton. Br. Food J. 2017, 119, 1815-1825. [CrossRef]

5. Zheng, Y.; Chi, T. Factors influencing purchase intention towards environmentally friendly apparel: An empirical study of US consumers. Int. J. Fash. Des. Tech. Ed. 2015, 8, 68-77. [CrossRef]

6. Allwood, J.M.; Laursen, S.E.; Rodríguez, C.M.; Bocken, N.M.P. Well dressed? The present and future sustainability of clothing and textiles in the United Kingdom. Univ. Camb. Inst. Manuf. 2015, 22, 42.

7. Chi, T. Building a sustainable supply chain: An analysis of corporate social responsibility (CSR) practices in the Chinese textile and apparel industry. J. Text. Inst. 2011, 102, 837-848. [CrossRef]

8. Jakhar, S.K. Performance evaluation and a flow allocation decision model for a sustainable supply chain of an apparel industry. J. Clean. Prod. 2015, 87,391-413. [CrossRef]

9. Dockterman, E. Eco Chic_Time. Available online: http://content.time.com/time/magazine/article/0,9171, 2121658,00.html (accessed on 2 September 2014).

10. Thiry, M.C. Staying Alive: Making Textiles Sustainable. AATCC Rev. 2011, 11, 26-32. Available online: http://www.aatcc.org/media/read/documents/sustain1111.pdf (accessed on 3 September 2014).

11. Ha-Brookshire, J.E.; Norum, P.S. Willingness to pay for socially responsible products: Case of cotton apparel. J. Consum. Mark. 2011, 28, 344-353. [CrossRef]

12. Cotton Incorporated. Cotton Leads 2014. Available online: https://www.cottonworks.com/wp-content/ uploads/2017/11/CottonLEADSprogram.pdf (accessed on 11 February 2018).

13. Radhakrishnan, S. Sustainable cotton production. In Sustainable Textiles: Life Cycle and Environmental Impact; Woodhead Publishing: Cambridge, UK, 2017; pp. 21-67.

14. Zhang, Y.; Liu, X.; Xiao, R.; Yuan, Z. Life cycle assessment of cotton T-shirts in China. Int. J. Life Cycle Assess. 2015, 20, 994-1004. [CrossRef]

15. Cotton Incorporated. Responsible Cotton Manufacturing 2018. Available online: https://www.cottonworks.com/ topics/sustainability/cotton-sustainability/responsible-cotton-manufacturing (accessed on 11 February 2018).

16. Cotton Leads. Partners Lead the Way 2018. Available online: https://cottonleads.org/program-partnership/ (accessed on 1 June 2018).

17. IBISWorld. Athletic \& Sporting Goods Manufacturing-US Market Research Report 2018. Available online: https://www.ibisworld.com/industry-trends/market-research-reports/manufacturing/miscellaneous/ athletic-sporting-goods-manufacturing.html (accessed on 10 March 2018).

18. Kwon, H.H.; Trail, G.; James, J.D. The mediating role of perceived value: Team identification and purchase intention of teamlicensed apparel. J. Sport Manag. 2007, 21, 540-554. [CrossRef]

19. Green, D. Athleisure is Not Just a Trend-It's a Fundamental Shift in How Americans Dress 2017. Available online: http://www.businessinsider.com/athleisure-is-more-than-a-trend-2017-2 (accessed on 1 March 2019).

20. Ajzen, I.; Fishbein, M. Attitudinal and normative variables as predictors of specific behaviors. J. Personal. Soc. Psychol. 1973, 27, 41-57. [CrossRef]

21. Al Mamun, A.; Mohiuddin, M.; Ahmad, G.B.; Thurasamy, R.; Fazal, S.A. Recycling intention and behavior among low-income households. Sustainability 2018, 10, 2407. [CrossRef]

22. Chi, T.; Zheng, Y. Understanding environmentally friendly apparel consumption: An empirical study of Chinese consumers. Int. J. Sustain. Soc. 2016, 8, 206-227. [CrossRef]

23. Maya, S.R.; López-López, I.; Munuera, J.L. Organic food consumption in Europe: International segmentation based on value system differences. Ecol. Econ. 2011, 70, 1767-1775. [CrossRef]

24. Ajzen, I. The theory of planned behavior. Organ. Behav. Hum. Decis. Process. 1991, 50, 179-211. [CrossRef]

25. Lee, K. Opportunities for green marketing: Young consumers. Mark. Intell. Plan. 2008, 26, 573-586. [CrossRef] 
26. Johnstone, M.-L.; Tan, L.P. Exploring the gap between consumers green rhetoric and purchasing behavior. J. Bus. Ethics 2015, 132, 311-328. [CrossRef]

27. Paul, J.; Modi, A.; Patel, J. Predicting green product consumption using theory of planned behavior and reasoned action. J. Retail. Consum. Serv. 2016, 29, 123-134. [CrossRef]

28. Chen, K.; Deng, T. Research on the Green Purchase Intentions from the Perspective of Product Knowledge. Sustainability 2016, 8, 943. [CrossRef]

29. Nam, C.; Dong, H.; Lee, Y. Factors influencing consumers' purchase intention of green sportswear. Fash. Text. 2017, 4, 1-17. [CrossRef]

30. Ko, S.B. Predictors of Purchase Intention toward Green Apparel Products in the US and China. Ph.D. Thesis, Oklahoma State University, Stillwater, MH, USA, 2012.

31. Ajzen, I. Perceived behavioral control, self-efficacy, locus of control, and the theory of planned behavior. J. Appl. Soc. Psychol. 2002, 32, 665-683. [CrossRef]

32. Armitage, C.J.; Talibudeen, L. Test of a brief theory of planned behavior-based intervention to promote adolescent safe sex intentions. Br. J. Psychol. 2010, 101, 155-172. [CrossRef]

33. Kim, Y.H.; Chung, J.E. Consumer purchase intention for organic personal care products. J. Consum. Mark. 2011, 28, 40-47.

34. Joergens, C. Current research development ethical fashion: Myth or future trend? J. Fash. Mark. Manag. Int. J. 2006, 10, 360-371.

35. Kinnear, T.C.; Taylor, J.R.; Ahemd, S.A. Ecologically concerned consumers: Who are they? J. Mark. 1974, 38, 20-25. [CrossRef]

36. Jin, B.; Kang, J.H. Purchase intention of Chinese consumers toward a U.S. apparel brand: A test of a composite behavior intention model. J. Consum. Mark. 2011, 28, 187-199. [CrossRef]

37. Tan, B.C.; Lau, T.C. Green purchase behavior: Examining the influence of green environmental attitude, perceived consumer effectiveness and specific green purchase attitude. Aust. J. Basic Appl. Sci. 2011, 5, 559-567.

38. Berger, I.E.; Corbin, R.M. Perceived consumer effectiveness and faith in others as moderators of environmentally responsible behaviors. J. Public Policy Mark. 1992, 11, 79-89. [CrossRef]

39. Ellen, P.S.; Wiener, J.L.; Cobb-Walgren, C. The role of perceived consumer effectiveness in motivating environmentally conscious behaviors. J. Public Policy Mark. 1991, 10, 102-118. [CrossRef]

40. Roberts, J.A. Green consumer in the 1990s: Profile and implications for advertising. J. Bus. Res. 1996, 36, 217-231. [CrossRef]

41. Haron, S.A.; Paim, L.; Yahaya, N. Towards sustainable consumption: An examination of environmental knowledge among Malaysians. Int. J. Consum. Stud. 2005, 29, 426-436. [CrossRef]

42. Momberg, D.; Jacobs, B.; Sonnenberg, N. The role of environmental knowledge in young female consumers' evaluation and selection of apparel in South Africa. Int. J. Consum. Stud. 2005, 36, 408-415. [CrossRef]

43. Wang, P.; Liu, Q.; Qi, Y. Factors influencing sustainable consumption behaviors: A survey of the rural residents in China. J. Clean. Prod. 2014, 63, 152-165. [CrossRef]

44. D'Souza, C.; Taghian, M.; Lamb, P. An empirical study on the influence of environmental labels on consumers. Corp. Commun. Int. J. 2006, 11, 162-173. [CrossRef]

45. Aman, A.; Harun, A.; Hussein, Z. The influence of environmental knowledge and concern on green purchase intention the role of attitude as a mediating variable. Br. J. Arts Soc. Sci. 2012, 7, 145-167.

46. Barbarossa, C.; De Pelsmacker, P. Positive and negative antecedents of purchasing eco-friendly products: A comparison between green and non-green consumers. J. Bus. Ethics 2016, 134, 229-247. [CrossRef]

47. Lee, K. The green purchase behavior of Hong Kong young consumers: The role of peer influence, local environmental involvement, and concrete environmental knowledge. J. Int. Consum. Mark. 2011, 23, 21-44. [CrossRef]

48. Yadav, R.; Pathak, G.S. Young consumers' intention towards buying green products in a developing nation: Extending the theory of planned behavior. J. Clean. Prod. 2016, 135, 732-739. [CrossRef]

49. Mostafa, M.M. A hierarchical analysis of the green consciousness of the Egyptian consumer. Psychol. Mark. 2007, 24, 445-473. [CrossRef]

50. Chi, T.; Sun, Y. Development of firm export market oriented behavior: Evidence from an emerging economy. Int. Bus. Rev. 2013, 22, 339-350. [CrossRef] 
51. Mariadoss, B.J.; Chi, T.; Tansuhaj, P.; Pomirleanu, N. Influences of firm orientations on sustainable supply chain management. J. Bus. Res. 2016, 69, 3406-3414. [CrossRef]

52. Goodman, J.K.; Cryder, C.E.; Cheema, A. Data collection in a flat world: The strengths and weaknesses of Mechanical Turk samples. J. Behav. Decis. Mak. 2013, 26, 213-224. [CrossRef]

53. Dillman, D.A.; Smyth, J.D.; Christian, L.M. Internet, Phone, Mail, and Mixed-Mode Surveys: The Tailored Design Method; John Wiley \& Sons: Hoboken, NY, USA, 2014.

54. Byrne, B. Structural Equation Modeling with Lisrel, Prelis, \& Simplis: Basic Concepts, Applications, E Programming; Erlbaum: Mahwah, NJ, USA, 1998.

55. Ott, L.; Longnecker, M.; Ott, R.L. An Introduction to Statistical Methods and Data Analysis; Duxbury: Pacific Grove, CA, USA, 2001.

56. Cadogan, J.W.; Cui, C.; Morgan, R.E.; Story, V. Factors facilitating and impeding the development of export market-oriented behavior: A study of Hong Kong manufacturing exporters. Ind. Mark. Manag. 2006, 35, 634-647. [CrossRef]

57. Morgan, N.A.; Vorhies, D.W.; Mason, C. Market orientation, marketing capabilities and firm performance. Strateg. Manag. J. 2009, 30, 909-920. [CrossRef]

58. Ping, R.A. A parsimonious estimation technique for interaction and quadratic latent variables. J. Mark. Res. 1995, 32, 336-347. [CrossRef]

59. Ping, R.A. On assuring valid measures for theoretical models using survey data. J. Bus. Res. 2004, 57, $125-141$. [CrossRef]

60. Chi, T.; Kilduff, P.P. Understanding consumer perceived value of casual sportswear: An empirical study. J. Retail. Consum. Serv. 2011, 18, 422-429. [CrossRef]

61. Field, A. Discovering Statistics Using SPSS; Sage Publications: Thousand Oaks, CA, USA, 2009.

62. Yoo, B.; Donthu, N. Developing and validating a multidimensional consumer-based brand equity scale. J. Bus. Res. 2001, 52,1-14. [CrossRef]

63. Jöreskog, K.G.; Sörbom, D. Interactive LISREL 8.80; Scientific Software International: Chicago, IL, USA, 2006.

64. Nunnally, J.C.; Bernstein, I.H. Psychometric Theory, 2nd ed.; McGraw-Hill: New York, NY, USA, 1978.

65. Fornell, C.; Larcker, D.F. Structural equation models with unobservable variables and measurement error: Algebra and statistics. J. Mark. Res. 1981, 18, 382-388. [CrossRef]

66. Cohen, J.; Cohen, P. Applied Multiple Regression/Correlation Analysis for the Behavioral Sciences; Lawrence Erlbaum Associates: Hillsdale, NJ, USA, 1975.

67. Maichum, K.; Parichatnon, S.; Peng, K. Application of the extended theory of planned behavior model to investigate purchase intention of green products among Thai consumers. Sustainability 2016, 8, 1077. [CrossRef]

68. Hughner, R.S.; McDonagh, P.; Prothero, A.; Shultz, C.J.; Stanton, J. Who are organic food consumers? A compilation and review of why people purchase organic food. J. Consum. Behav. Int. Res. Rev. 2007, 6, 94-110. [CrossRef]

69. Van Doorn, J.; Verhoef, P.C. Drivers of and barriers to organic purchase behavior. J. Retail. 2015, 91, 436-450. [CrossRef]

(C) 2019 by the authors. Licensee MDPI, Basel, Switzerland. This article is an open access article distributed under the terms and conditions of the Creative Commons Attribution (CC BY) license (http://creativecommons.org/licenses/by/4.0/). 